\title{
PERANCANGAN SMARTHOME DENGAN RASBERRY BERBASIS WIRELESS MENGGUNAKAN MICROKONTOLLER AVR ATMEGA328 DAN FUZZY LOGIC
}

\author{
Desmira \\ Fakultas Keguruan dan Ilmu Pendidikan, Program Studi Pendidikan Teknik Elektro \\ Universitas Sultan Ageng Tirtayasa \\ Email: ides_syahidah@yahoo.com \\ Didik Aribowo \\ Fakultas Keguruan dan Ilmu Pendidikan, Program Studi Pendidikan Teknik Elektro \\ Universitas Sultan Ageng Tirtayasa \\ Email: d_aribowo@untirta.ac.id
}

\begin{abstract}
ABSTRAK
Kebutuhan Energi listrik yang diperlukan untuk kehidupan manusia sehari-hari sangat meningkat. Penggunaan energi listrik dewasa ini tidak sesuai dengan penggunaan pada umumnya yang membiarkan peralatan elektronik atau penerangan pada sebuah rumah tetap menyala pada saat tidak dipergunakan. Dengan peristiwa tersebut, terpikirlah untuk menghasilkan Smarthome yang dapat mengontrol peralatan elektronik dari jauh menggunakan Mini PC Raspberry pi dan Smartphone android. Pemanfaatan Raspberry pi adalah untuk mengontrol dan memonitoring peralatan elektronik melalui web yang diperintahkan oleh Smartphone Android, kemudian dikomunikasikan kepada mikrokontroller AVR ATMega328 untuk menyalakan relay yang tersambung ke perangkat elektronik. Berdasarkan pembahasan dan pengujian, dapat ditemukan kelebihan dan kelemahan rancangan Smarthome menggunakan Raspberry berkomunikasi Wireless berbasis Microcontroller AVR ATMega328. Dalam sistem ini, user melakukan komunikasi dari aplikasi android menuju Raspberry yang kemudian dikirimkan oleh transiver dan diterima oleh reciver lalu dibaca oleh mikrokontroler yang membuat lampu atau alat elektronik menyala. Dengan demikian dapat memberikan solusi dalam mengontrol perangkat elektronik yang ada di dalam rumah dengan cara pengontrolan terpusat pada sebuah Smartphone android disertai media internet yang meringankan kerja manusia dan mengoptimalisasikan kenyamanan dan keamanaan dari sebuah rumah.
\end{abstract}

Kata kunci: rumah pintar, mini pc, raspberry pi, android smartphone, mikrokontroler AVR ATmega328.

\begin{abstract}
The electrical energy needs necessary for everyday human life greatly improved. The use of electrical energy today is not in accordance with the ordinary use that allow electronic equipment or lighting in a home stays on when not in use. With these events, terpikirlah to produce Smarthome that can control electronic devices remotely using the Mini PC Raspberry pi and android Smartphone. Utilization Raspberry pi is to control and monitor electronic equipment via the web are ordered by Android Smartphone, and then communicated to the AVR ATmega328 Microcontroller to power the relay connected to the electronic device. Thus it can provide solutions to control electronic devices in the house by means of centralized control on an Android Smartphone with Internet media alleviate human work and optimize the comfort and security of a home.
\end{abstract}

Keywords: smart home, mini pc raspberry pi, smartphone android, microkontroller AVR ATMega328.

\section{PENDAHULUAN}

Sistem kendali atau sistem kontrol (control sistem) adalah suatu alat (kumpulan alat) untuk mengendalikan, memerintah, dan mengatur keadaan dari suatu sistem [1]. Tiga hal komponen yang perlu diperhatikan yaitu, Who, yaitu orang atau pihak yang akan di berikan hak agar bisa memasuki area tertentu. Access control secara unik juga memberikan sebuah identitas pada setiap orang yang berkepentingan dan otoritas untuk memasuki fasilitas tertentu. Where, yaitu menentukan tempat yang dapat digunakan atau dimasuki oleh orang-orang yang memiliki kewenangan atau kepentingan atas tempat tersebut. Kemudian Control system mengelola kemanan orang-orang dapat pergi dengan 
memberikan akses ke pintu gerbang elevator dan sarana-sarana jalan masuk yang ada. Terakhir When yaitu menentukan waktu kapan seseorang dapat memasuki ruang atau area tertentu dan juga dapat diartikan sebagai pencatatan aktifitas mobilitas orang-orang pada wilayah tertentu.

Perancangan sebuah sistem yang dapat digunakan untuk mengendalikan lampu dan pompa air listrik yang berada di rumah dari jarak jauh dengan antarmuka halaman web yang dapat diakses menggunakan jaringan internet atau tanpa jaringan internet melalui PC atau Smartphone. Sistem yang dibuat ini juga memiliki fasilitas penjadwalan dan dapat digunakan untuk pemantauan suhu ruangan [2]. Raspberry Pi merupakan komputer mungil seukuran dengan sebuah kartu kredit dengan berbagai fungsi yang dapat dilakukannya. Raspberry Pi menggunakan sistem operasi Raspbian. Raspberry memiliki prosesor yang memiliki spesifikasi 700MHz ARM11. Ada 2 tipe dari Raspberry Pi yakni tipe A dan B. Pada Tipe B RAM yang dimiliki adalah sebesar 512 MB. Raspberry Pi menggunakan SD Card sebagai media penyimpanannya. Selain itu Raspberry juga dilengkapi 2 buah port USB untuk tipe B, konektor HDMI, lalu untuk tipe B, Raspberry Pi dilengkapi dengan port ethernet. Pada Raspberry Pi tidak disediakan switch power. Port micro USB pada Raspberry Pi digunakan sebagai power supply, penggunaan micro USB di karenakan murah dan mudah di dapatkan. Raspberry Pi membutuhkan supply sebesar 5V dengan arus minimal 700mA untuk tipe B dan 500mA untuk tipe A [3].

Smartphone adalah sebuah device yang memungkinkan untuk melakukan komunikasi seperti menelepon atau sms dan juga di dalamnya terdapat fungsi PDA (Personal Digital Assistant) serta berkemampuan seperti layaknya komputer [4]. Sistem operasi yang digunakan pada telepon seluler pintar berbeda - beda tetapi yang paling banyak digunakan saat ini adalah sistem operasi yang berbasis android dari google. Microcontroller AVR (Alf and Vegard's Risc Processor) dari Atmel ini menggunakan arsitektur RISC (Reduced Instruction Set Computer) yang artinya prosesor tersebut memiliki set instruksi program yang lebih sedikit dibandingkan dengan MCS-51 yang menerapkan arsitektur CISC (Complex Instruction Set Computer) [5]. ATMega328 memiliki 3 buah PORT utama yaitu PORTB, PORTC, dan PORTD dengan total pin input atauoutput sebanyak 23 pin. PORT tersebut dapat difungsikan sebagai input atau output digital atau difungsikan sebagai periperial lainnya [6].

Lampu LED atau kepanjangannya Light Emitting Diode adalah suatu lampu indikator dalam perangkat elektronika yang bisaanya memiliki fungsi untuk menunjukkan status dari perangkat elektronika [7]. Fungsi LED merupakan sejenis lampu yang akhir-akhir ini muncul dalam kehidupan kita. LED dulu umumnya digunakan pada 27 gadget seperti ponsel atau PDA serta komputer. Sebagai pesaing lampu bohlam dan neon, saat ini aplikasinya mulai meluas dan bahkan bisa kita temukan pada korek api yang kita gunakan, lampu emergency dan sebagainya. LED sebagai model lampu masa depan dianggap dapat menekan pemanasan global karena efisiensinya.

Logika fuzzy digunakan untuk menterjemahkan suatu besaran yang diekspresikan menggunakan bahasa (linguistic), misalkan besaran kecepatan laju kendaraan yang diekspresikan dengan pelan, agak cepat, cepat, dan sangat cepat. Dan logika fuzzy menunjukan sejauh mana suatu nilai itu benar dan sejauh mana suatu nilai itu salah. Beberapa bahasan yang dapat dikaji pada sistem fuzzy antara lain: system inferensi fuzzy (Fuzzy inference system) dan ada beberapa metode yang digunakan antara lain: metode mamdani, metode TSK dan metode Tsukamoto [8]. Fuzzifikasi adalah suatu proses untuk merubah suatu masukan dari bentuk tegas (crisp) menjadi fuzzy (variabel linguistik) yang biasanya disajikan dalam bentuk himpunan-himpunan fuzzy dengan suatu fungsi keanggotaannya masing-masing [9].

\section{METODOLOGI PENELITIAN}

Dalam penelitian ini akan merancang sistem kendali smarthome berbasis mikrokontroler AVR ATMega328 dengan tujuan untuk meminimalkan penggunaan energi listrik yang tidak terpakai yang dapat mengakibatkan arus pendek. Dengan pengendalian menggunakan Smartphone Android ini akan memudahkan pengguna alat ini untuk menghidupkan atau mematikan tegangan listrik sesuai dengan jalur mana yang kita inginkan, karena fitur Smartphone Android yang dapat terhubung dengan alat ini melalui media wireless. Peneliti membagi menjadi 3 (tiga) bagian, dimana bagian pertama, yaitu bagian input yang di dalamnya terdapat komponen serta rangkaian mikrokontroler. Bagian kedua yaitu bagian output yang di dalamnya terdapat relay yang dapat menghentikan atau mengalirkan tegangan listrik sama halnya seperti saklar. Bagian ketiga software yang digunakan peneliti untuk mendukung alat ini, yaitu Raspberry Phyton, Arduino IDE dan Android Studio. 


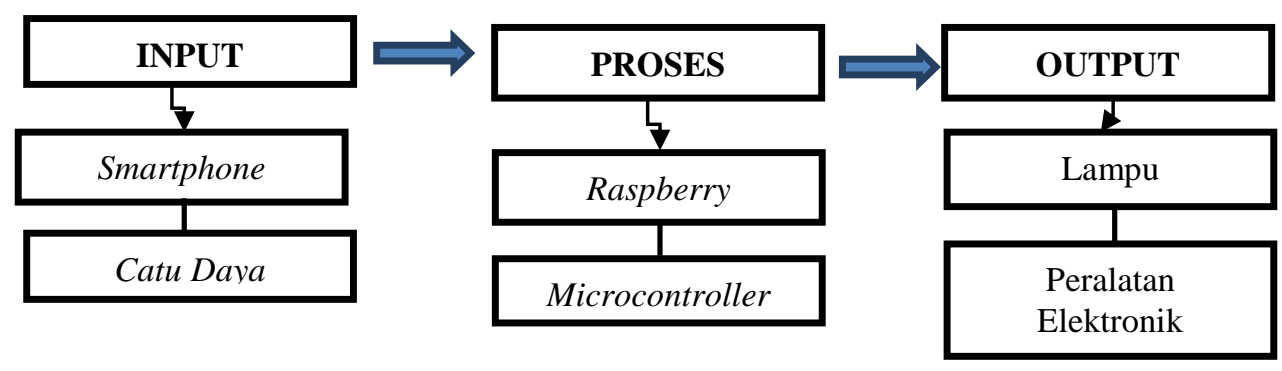

Gambar 1. Blok Diagram Perancangan Penelitian

Pada perancangan program, terdapat beberapa program yang dimasukan untuk dapat menjalankan Smarthome. Adapun flowchart untuk melihat detail perancangan dan kerjanya sebagai berikut:

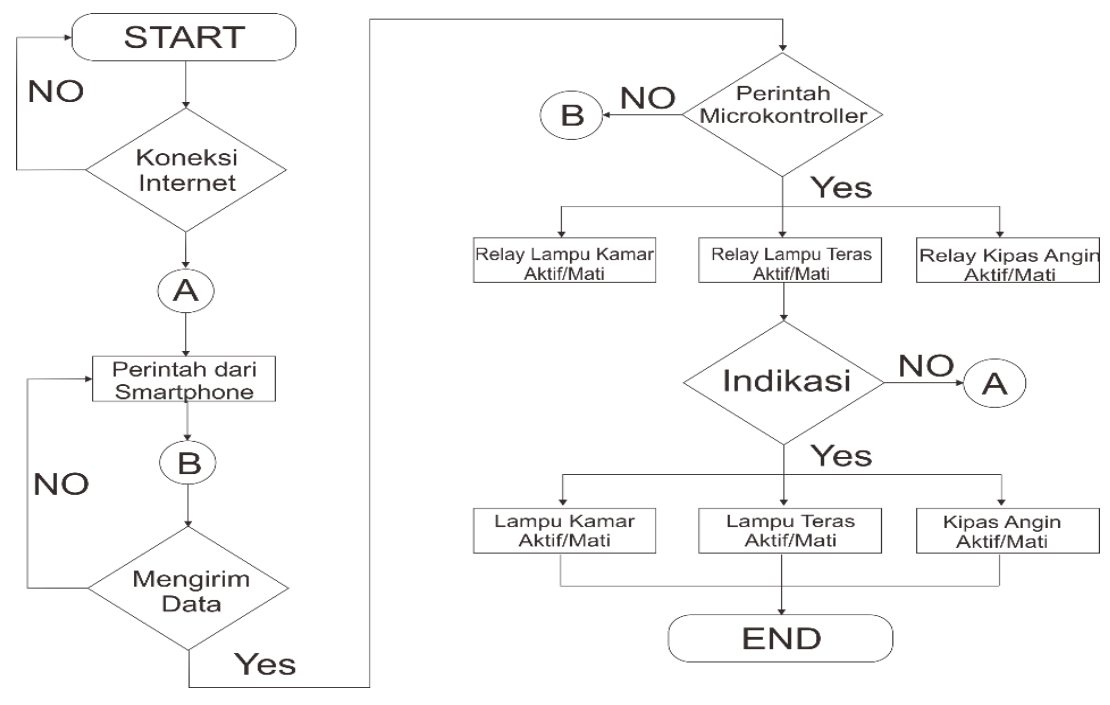

Gambar 2. Diagram Alir Raspberry

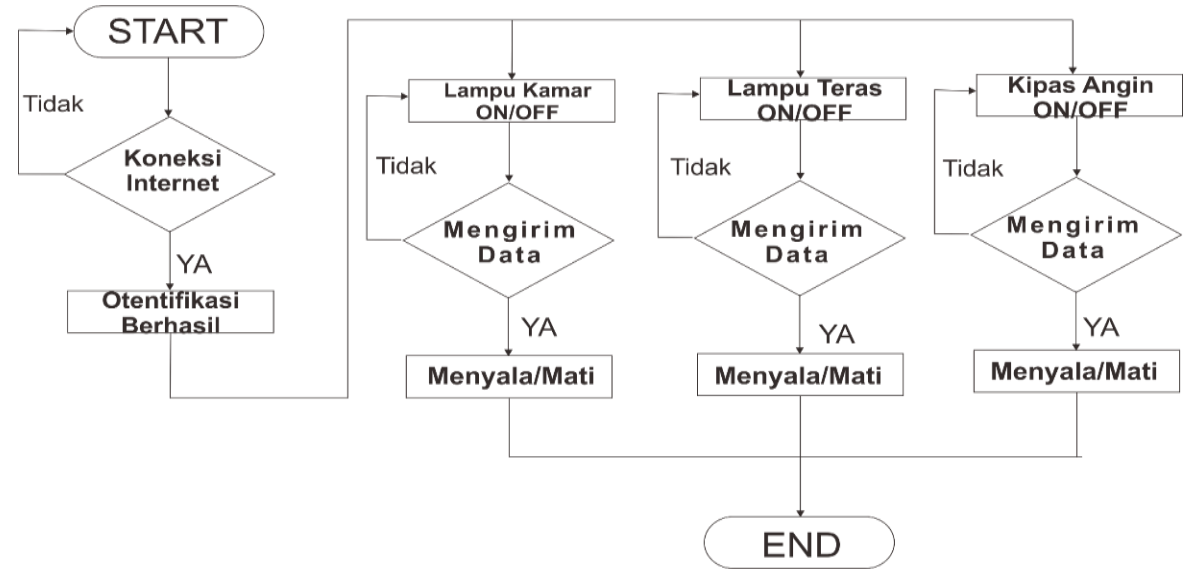

Gambar 3. Diagram Alir Perintah Smartphone

\section{HASIL DAN PEMBAHASAN}

\subsection{Kontruksi Sistem (Coding)}

\subsubsection{Microkontroller AVR ATMega 328}

Berdasarkan alat yang dibuat, peneliti menggunakan bahasa $\mathrm{C}$ untuk memasukan program ke dalam Microkontroller ATMega328 dengan menggunakan software Arduino IDE sebagai downloader programnya, script programnya sebagai berikut: 


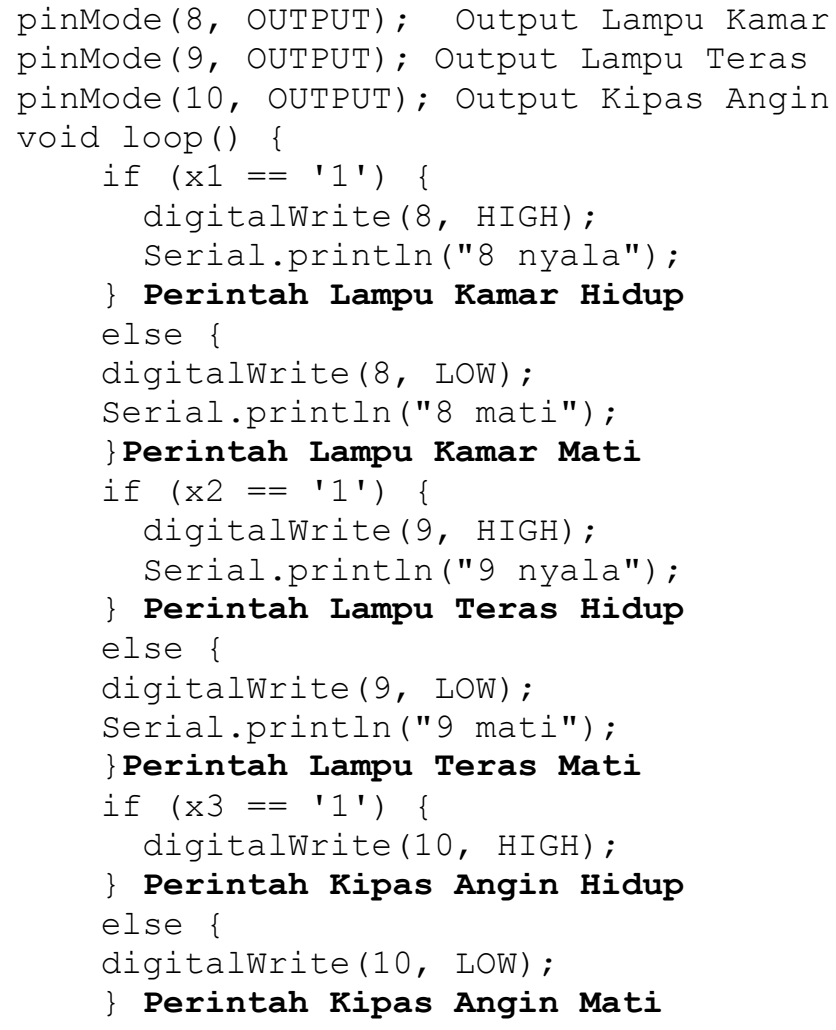

\subsubsection{Raspberry}

Pada proses Raspberry perancangan menggunakan bahasa pemrograman Phyton yang berada pada Raspberry itu sendiri

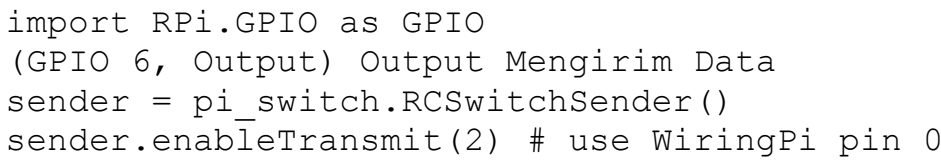

\subsubsection{Smartphone}

Berdasarkan program layout yang dibuat, peneliti menggunakan tiga tombol Switch button dan satu tombol Toggle Button pada aplikasi android studio, yang pada umumnya android studio ini menggunakan pemrograman java. Adapun koding yang berfungsi untuk menentukan switch sebagai berikut :

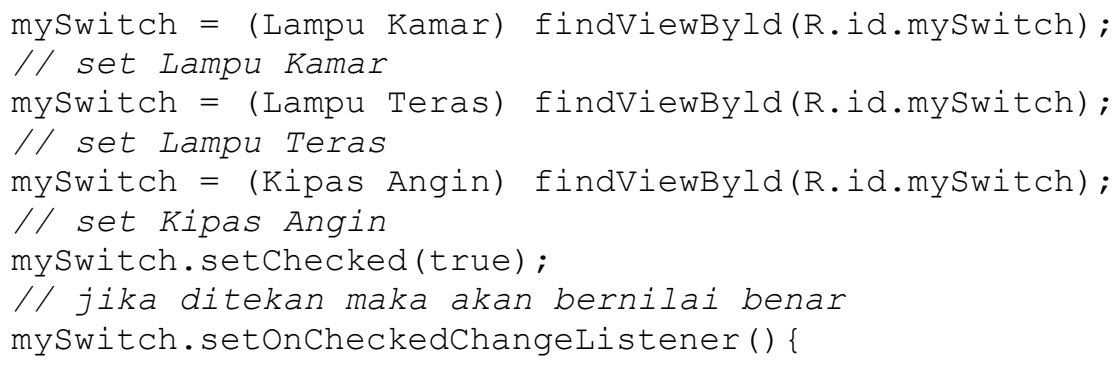

Hasil pengujian dari rancangan Smarthome menggunakan Raspberry berkomunikasi Wireless berbasis Microcontroller AVR ATMega328, yaitu sebagai berikut :

1) Input

Pengujian ini dilakukan dengan mengganti kartu sim untuk menentukan baik atau buruk koneksi yang digunakan untuk mengirim data dari Smartphone. Pengujian koneksi ini dilakukan di kota cilegon, adapun hasil pengujian dalam bentuk tabel seperti berikut: 
Tabel 1. Pengujian koneksi

\begin{tabular}{rcc}
\hline No & Kartu Sim & Koneksi \\
\hline 1 & Telkomsel & Bagus \\
2 & Three (3) & Sedang \\
3 & XL & Bagus \\
4 & Axis & Sedang \\
5 & Indosat & Buruk \\
\hline
\end{tabular}

2) Proses

Hasil pengujian tegangan pada Microkontroller ini bertujuan untuk mengetahui pada tegangan berapa Microkontroller berfungsi atau tidaknya. Berikut tabel pengujian tegangan pada Microkontroller:

Table 2. Pengujian tegangan pada microkontroller

\begin{tabular}{rcc}
\hline No & Tegangan & Koneksi \\
\hline 1 & 12Volt & On \\
2 & 9 Volt & On \\
3 & 7,5 Volt & On \\
4 & 5 Volt & On \\
5 & 3 Volt & Off \\
6 & 1,5 Volt & Off \\
\hline
\end{tabular}

3) Output

Pada hasil pengujian jarak ini, diambil pada saat Raspberry dijauhkan dengan Microkontroller yang diletakan bersama dengan lampu atau kipas angin. Adapun pengujian jarak ini dituliskan dalam bentuk tabel sebagai berikut:

Tabel 3. Pengujian jarak

\begin{tabular}{cccc}
\hline No & Jarak Jangkauan & Jeda Waktu & Lampu \\
\hline 1 & 1 Meter & $0,5 \mathrm{~S}$ & On \\
2 & 2 Meter & $0,5 \mathrm{~S}$ & On \\
3 & 3 Meter & $0,5 \mathrm{~S}$ & On \\
4 & 4 Meter & $0,5 \mathrm{~S}$ & On \\
5 & 5 Meter & $0,5 \mathrm{~S}$ & On \\
6 & 6 Meter & $1 \mathrm{~S}$ & On \\
7 & 7 Meter & $1 \mathrm{~S}$ & On \\
8 & 8 Meter & $1 \mathrm{~S}$ & On \\
9 & 9 Meter & $1 \mathrm{~S}$ & On \\
10 & 10 Meter & $1 \mathrm{~S}$ & On \\
11 & 11 Meter & $1 \mathrm{~S}$ & On \\
12 & 12 Meter & $1,5 \mathrm{~S}$ & On \\
13 & 13 Meter & $1,5 \mathrm{~S}$ & On \\
14 & 14 Meter & $1,5 \mathrm{~S}$ & On \\
15 & 15 Meter & $1,5 \mathrm{~S}$ & On \\
16 & 16 Meter & $1,5 \mathrm{~S}$ & On \\
\hline
\end{tabular}

Berdasarkan pembahasan dan pengujian, dapat ditemukan kelebihan rancangan Smarthome menggunakan Raspberry berkomunikasi Wireless berbasis Microcontroller AVR ATMega328 seperti berikut:
a. Efesiensi waktu dan tenaga.
b. Praktis untuk digunakan.
c. Pengguna dapat melakukan kendali perangkat elektronik ini dalam jarak jauh karena terhubung ke internet.
d. Aman. 
e. Feedback dalam sistem ini memudahkan pengguna mendapatkan informasipada peralatan elektronik/ lampu.

Sedangkan kelemahan rancangan Smarthome menggunakan Raspberry berkomunikasi Wireless berbasis Microcontroller AVR ATMega328 seperti berikut:

a. Program yang digunakan sedikit sulit karena perangkat Raspberryharus terhubung dan membuat data pada akun google.

b. Biaya perangkat yang cukup mahal.

c. Antena pada wirelessmodule $433 \mathrm{MHz}$ harus berposisi vertikal.

Untuk menentukan kinerja Koneksi dipengaruhi oleh 5 himpunan, yaitu Sangat Buruk (SB), Buruk (B), Cukup (C), Sedang (S) dan Bagus (Bgs). Kinerja Koneksi terbagi atas dua kategori, yaitu BAIK dan JELEK, masing-masing dengan fungsi keanggotaannya.

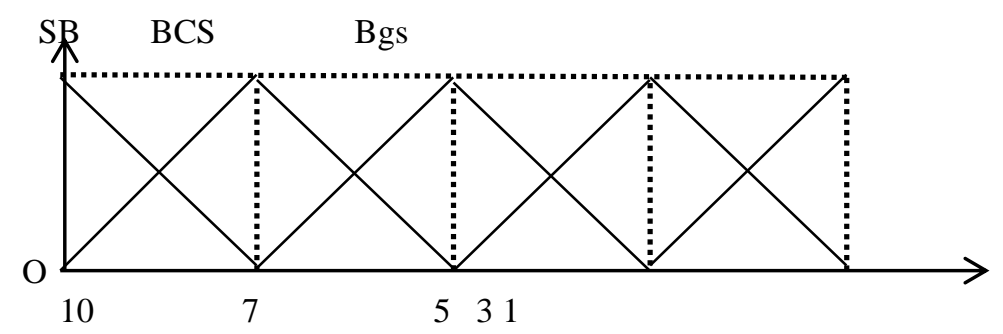

Gambar 4. Himpunan Fuzzy Untuk Setiap Variable Pada Anteseden [8]

Fungsi keanggotaan untuk setiap himpunan adalah:

1) Himpunan sangat buruk (SB)

$\mu \mathrm{SB}(\mathrm{X})=\frac{7-X}{7} ; 0 \geq x \geq 7$
$0 ; x \leq 7$

2) Himpunan Buruk (B)

$$
\begin{aligned}
& \mu \mathrm{R}(\mathrm{x})=\frac{x}{7} ; 0 \geq \mathrm{x} \geq 7 \\
& \frac{5-x}{7}: 7 \geq x \geq 5 \\
& 0 ; x \leq 7
\end{aligned}
$$

3) Himpunan Cukup (C)

$0: x \geq 7$ atau $x \leq 3$

$\mu \mathrm{c}(\mathrm{X})=\frac{x-7}{7} ; 7 \geq x \geq 5$

$\frac{3-x}{7}: 5 \geq x \geq 3$

4) Himpunan Sedang (S)

$$
\begin{aligned}
& 0 ; x \leq 5 \\
& \mu \mathrm{T}(\mathrm{X})=\frac{x-5}{7} ; 5 \geq x \geq 3 \\
& \frac{3-x}{7} ; 5 \geq x \geq 3
\end{aligned}
$$


5) Himpunan Bagus (Bgs)

$0 ; x \leq 3$

$\mu \mathrm{ST}(\mathrm{X})=\frac{x-3}{7}, 3 \geq x \geq 1$

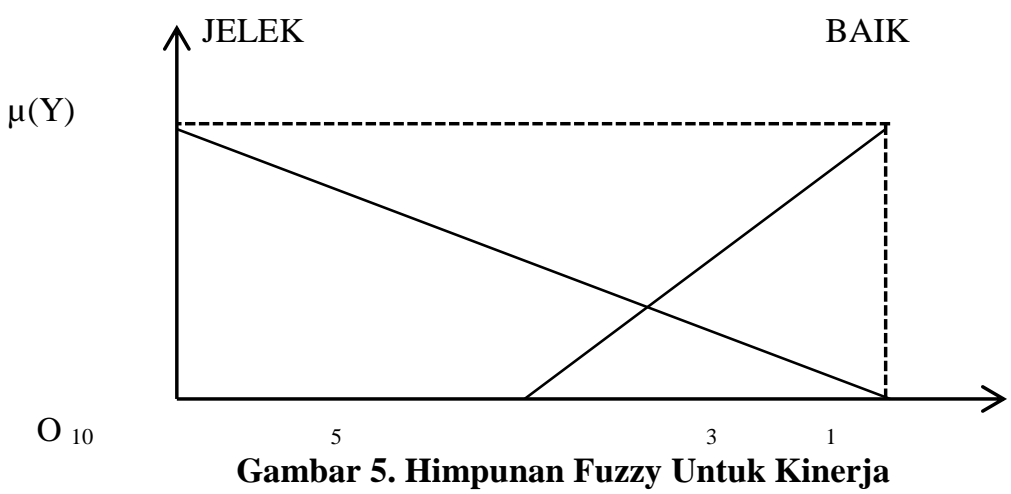

Fungsi keanggotaan untuk setiap himpuan adalah:

1) Himpunan Jelek

$$
\begin{aligned}
& \mu \text { Jelek }(y)=\frac{3-y}{7} ; 0 \leq y \leq 3 \\
& 0 ; y \geq 3
\end{aligned}
$$

2) Himpunan Baik

$$
\begin{aligned}
& 0 ; y \leq 7 \\
& \mu \mathrm{BAIK}(\mathrm{y})=\frac{y-5}{5} ; 5 \leq y \leq 1
\end{aligned}
$$

Dalam sistem ini, user melakukan komunikasi dari aplikasi android menuju Raspberry yang kemudian dikirimkan oleh transiver dan diterima oleh reciver lalu dibaca oleh mikrokontroler yang membuat lampu atau alat elektronik menyala. Input yang dipakai berupa input standar yaitu switchbutton. Data yang dimasukkan berupa data digital yang dikirim ke arduino melalui Wireless. Data yang dikirim dari Android akan diterima oleh modul wireless yang ada dalam sistem mikrokontroller. Data digital tersebut diterjemahkan oleh mikrokontroller menjadi data pararel. Data pararel yang dihasilkan oleh mikrokontroller diteruskan relay. Jika sampai tahap ini proses berjalan lancar, kemudian relay akan meneruskan data yang digunakan untuk mengaktifkan lane tegangan listrik yang berfungsi menyalakan peralatan elektronik. Feedback yang diterapkan berada pada aplikasi android. Apabila peralatan elektronik telah aktif, maka comand yang berada pada aplikasi android akan memberikan pesan "ON". Begitu juga sebaliknya. Kondisi peralatan elektronik saat hidup/mati dimanfaatkan sebagai input ke mikrokontroler. Data yang diperoleh dari mikrokontroler tersebut dikirimkan kembali ke perangkat android.

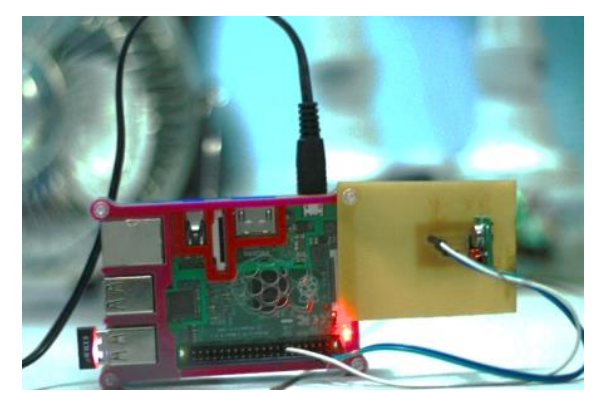

Gambar 6. Raspberry PI 
Pada gambar 6 merupakan Raspberry PI adalah komputer papan tunggal (Single Board Circuit atauSBC) yang memiliki ukuran sebesar kartu kredit. Raspberry $P i$ bisa digunakan untuk berbagai keperluan, seperti spreadsheet, game, bahkan bisa digunakan sebagai media player karena kemampuannya dalam memutar video high definition. Manfaat lainnya adalah bisa dibuat sebuah mini kit yang bisa dijadikan computer mini. "Fungsi OS Raspberry PI bisa bermacam-macam, salah satunya linux debian yang telah dipaket minikan.

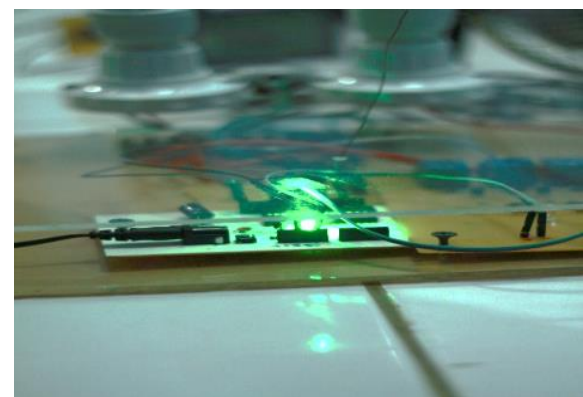

\section{Gambar 7. Microkontroller AVR ATMega 328}

Pada gambar 7 menjelaskan bahwa, ATMega328 merupakan mikrokontroler keluarga AVR 8 bit. Dari segi ukuran fisik, ATMega328 memiliki ukuran fisik lebih kecil dibandingkan dengan beberapa mikrokontroler diatas. Namun untuk segi memori dan periperial lainnya ATMega328 tidak kalah dengan yang lainnya karena ukuran memori dan periperialnya relatif sama dengan ATMega8535, ATMega32, hanya saja jumlah GPIO lebih sedikit dibandingkan mikrokontroler diatas.

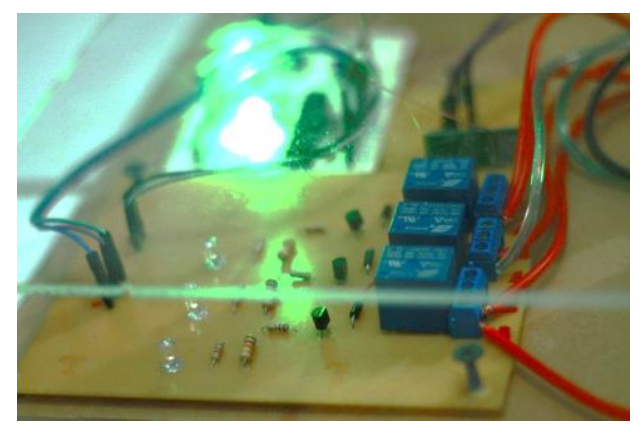

Gambar 8. Relay Output

Pada gambar 8, relay output bermaksud untuk mengaktifkan dan menonaktifkan beberapa peralatan elektronik atau lampu. Pertama mendeklarasikan variabel "karakter" yang bertugas untuk menghubungkan antara alat dengan Smartphone Android. Kemudian mendeklarasikan variabel "menyala" yang berfungsi menghubungkan antara peralatan elektronik dengan mikrokontroler.

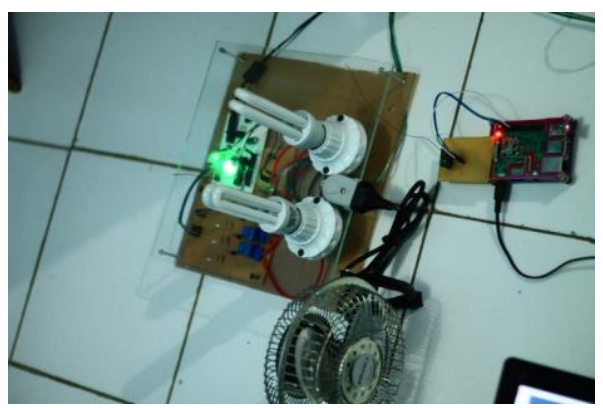

Gambar 9. Output Peralatan Elektronik

Pada gambar 9 ditampilkan bagaimana proses output dari peraalatan elektronika di mana data atau perintah yang dikirimkan dari Smartphone dan telah diproses oleh Raspberry dan Microkontroller ATMega328 akan membuat relay bekerja dan menghidupkan alat elektronik atau lampu. 


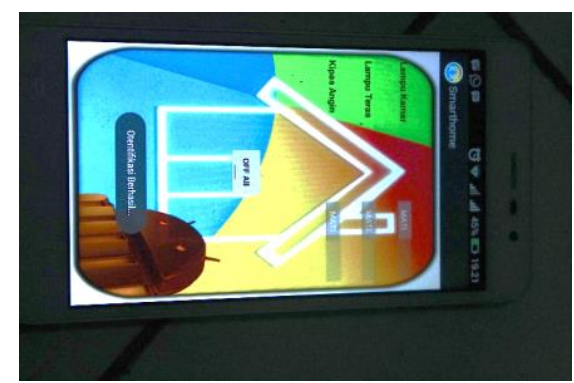

Gambar 10. Tampilan Smartphone Otentifikasi Berhasil

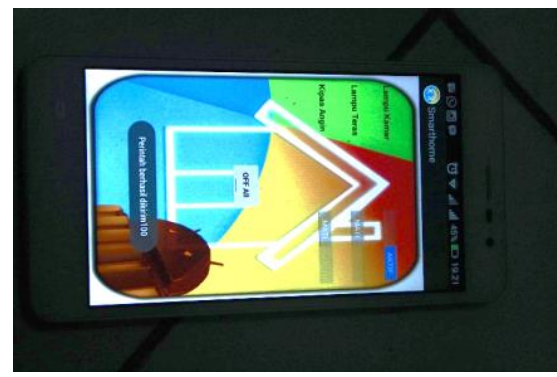

Gambar 11. Tampilan Perintah Dikirim

Pada gambar 10 menunjukkan bagaimana keberhasilan proses otentifikasi pada perangkat smarphone, sedangkan pada gambar 11 menunjukkan pada perangkat smarphone pada setiap perintah yang diinginkan oleh user untuk dapat dijalankan perintah tersebut.

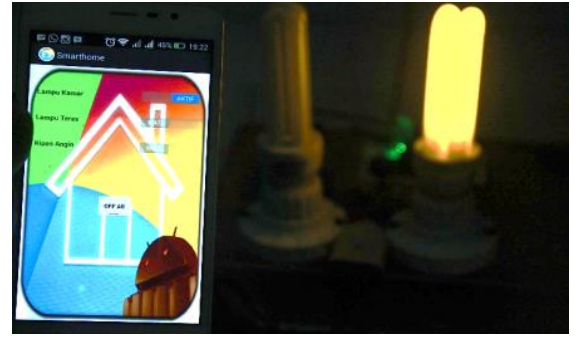

Gambar 12. Menyalakan Lampu Kamar

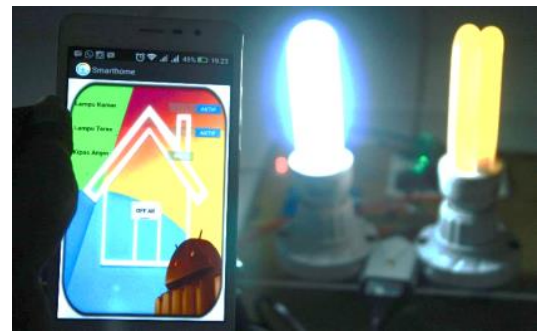

Gambar 13. Menyalakan Lampu Teras

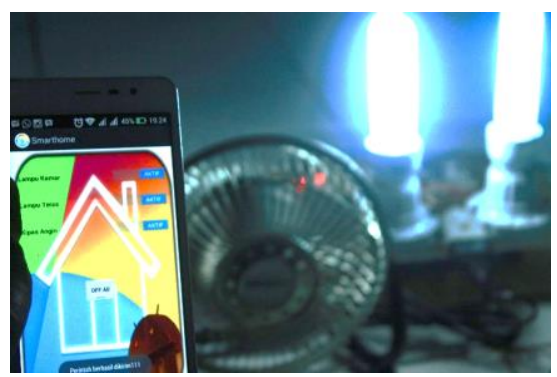

Gambar 14. Menyalakan Kipas Angin

Pada gambar 12 dan gambar 13 menunjukkan proses pemberian perintah untuk menyalakan komponen elektronik berupa lampu kamar dan lampu teras dengan menggunakan perangkat Smartphone. Pada proses tersebut menunjukkan hasil yang menggembirakan dikarenakan antara perangkat Smartphone dengan komponen elektronik terjadi proses sinkronisasi. Begitu juga halnya dengaan yang terjadi pada gambar 14 dilakukan pemberian perintah untuk menyalakan komponen elektronik berupa kipas angin dengan menggunakan perangkat Smartphone. Setelah dilakukan pengujian maka dapat menunjukkan keberhasilan dalam menjalankan perintah tersebut dengan baik.

\section{KESIMPULAN}

Berdasarkan penelitian yang telah dilakukan, peneliti menyimpulkan sebagai berikut:

1) Komunikasi antara Smartphone Android dengan Raspberry menggunakan media internet yang tersambung dengan akun google, sedangkan komunikasi antara Raspberry dengan Microcontroller untuk menghidupkan suatu alat dilakukan dengan menggunakan Wireless module.

2) Mikrokontroler AVR ATMega328 memerlukan beberapa komponen tambahan seperti Xtal, kapasitor, ic regulator dan resistor untuk dapat bekerja atau berfungsi sebagai mestinya.

3) Sebuah penggambaran yang penting untuk sebuah sistem rumah pintar yang dilakukan dalam penelitian ini yang mengunakan sebuah perangkat mini $p c$ - raspberry pi sebagai otak yang terhubung dengan jaringan yang dapat dikontol menggunakan Smartphone berbasiskan sistem operasi android 


\section{DAFTAR PUSTAKA}

[1] Choir, Affhol Arriska., 2012. Rancangan dan Uji Coba Otomatisasi Irigasi Kendi. Skripsi pada Institut Pertanian Bogor.

[2] Ignatius Prima Haryo Prabowo, Saptadi Nugroho, Darmawan Utomo, 2014, "Penggunaan Raspberry Pi Sebagai Web Server Pada Rumah Untuk Sistem Pengendali Lampu Jarak Jauh dan Pemantauan Suhu", Jurnal Ilmiah Elektroteknika, Vol. 13. No. 1. 111-124

[3] Nataliana. Decy, Syamsu. Iqbal, Giantara. Galih, 2014, "Sistem Monitoring Parkir Mobil menggunakan Sensor Infrared berbasis Raspberry Pi”, Jurnal Elkomika Institut Teknologi Nasional Bandung, Vol. 2. No. 1. 68-84.

[4] Mayasari, Hesti, SE, MM., 2012. "Analisa Perilaku Pembelian Ponsel Cerdas (Smartphone) : Antara Kebutuhan dan Gaya Hidup Konsumen Di Kota Padang”, Jurnal Manajemen dan Kewirausahaan Universitas Tamansiswa. Vol. 3. No. 1. 93-120

[5] Arifianto, Deni., 2011, Kumpulan Rangkaian Elektronika Sederhana, Jakarta, Kawan Pustaka.

[6] Syahid, 2012. "Rancang Bangun Robot Beroda Berbasis Android Menggunakan Komunikasi USB", Jurnal Teknik Elektro Politeknik Negeri Semarang.Vol.1. No. 2. 33-42

[7] Habi, Miftahul, 2013, "Analisis dan Perancangan Alat Praktikum Berbasis Mikrokontroler AT89S52”, Skripsi pada Universitas Serang Raya.

[8] Kusumadewi, Sri, 2010, Aplikasi Logika Fuzzy Untuk Pendukung Keputusan, Graha Ilmu.

[9] Tarigan, Pilipus, 2013, "Perancangan Alat Simulator Kontroler Lampu Rumah Berbasis Komputerisasi dengan Menggunakan Metode Fuzzy Logic Control”, Jurnal Pelita Informatika Budi Darma, Vol. 3. 56-62. 